\title{
Insights from 20 years of research in the Entlebuch UNESCO Biosphere Reserve
}

\author{
Florian Knaus, Annette Schmid \& Engelbert Ruoss
}

Keywords: UNESCO Biosphere Reserve, Entlebuch, research, impact, practice

\section{Abstract}

The $50^{\text {th }}$ anniversary of UNESCO's Man and the Biosphere (MAB) Programme coincides with the $20^{\text {th }}$ anniversary of the Entlebuch UNESCO Biosphere Reserve (EBR) in Switzerland. While the $M A B$ research framework has remained fairly constant since the EBR was established, the role of research in our institution and the ways it has been managed and implemented have changed significantly. After 20 years of research in the EBR, this is an opportune moment to highlight outputs, outcomes and impacts, and to draw conclusions regarding future challenges and developments for parks and their managements.
Profile

Protected area

Entlebuch Biosphere Reserve

Mountain range

Alps, Switzerland

\section{Introduction}

Entlebuch was endorsed as a UNESCO Biosphere Reserve in 2001. In the past 20 years, the area, the Biosphere Reserve management and research have all interacted continuously with each other while also developing independently. This article reviews this process, shedding light on the evolution, outputs and outcomes, and on the impacts that research has had in the Entlebuch UNESCO Biosphere Reserve (EBR). The review is based on personal experience and gives insights from three senior staff members working in the EBR for 20 (Annette Schmid, AS), 12 (Florian Knaus, FK) and 8 (Engelbert Ruoss, ER) years.

As a part of the UNESCO mandate, science was a prominent aspect of Biosphere Reserves (BRs) from the beginning of the Man and the Biosphere (MAB) Programme in the late 1970s (Batisse 1997). Driven by innovative scientists, the programme's first action plan (drawn up by Minsk in 1983) was at the forefront in terms of interdisciplinarity, long-term research, monitoring and remote sensing (UNESCO 1984; Reed 2020). However, the crucial framework for research in BRs was stipulated in the Seville Strategy in 1995, in which guiding principles relevant today were defined, such as research on sustainable development, local knowledge and transdisciplinarity (UNESCO 1996; Bouamrane et al. 2020). Further content was added, and some aspects given more priority in follow-up strategies and action plans, such as Ecosystem Services and Climate Change in the Madrid action plan (UNESCO 2008). New aspects for research are largely missing in the most recent strategy (2015-2025), which is defined in the Roadmap for the MAB Programme and includes the Lima Action Plan and Lima Declaration (UNESCO 2017). Based on our interpretation of past strategies and action plans, BRs are required to conduct interdisciplinary, transdisciplinary, collaborative, basic and applied research, as well as monitoring. These activities aim at providing a basis for evidence- based management for BRs, mutual learning by stakeholders, scientists and the public in the region of a BR, and within the world network of BRs.

\section{Implementation, evolution and outputs of research in the EBR}

The EBR adopted a BR research approach with the above-mentioned priorities along with the Seville Strategy. In the setting-up phase of the EBR, its management consisted of three site managers, one of whom (ER) was appointed director and scientific coordinator. As an active researcher himself, he was deeply engaged in the Swiss scientific community and had strong links to cantonal and national authorities, which attracted vast research interest for the Entlebuch area even before it was endorsed as a BR by UNESCO. In this first period, research was mostly driven by a strong network of scientists, universities and research institutions supported by cantonal and national authorities. The EBR was the first BR in Switzerland to apply a bottom-up approach, involving local communities in the BR's development and decision making. By contrast, the Swiss National Park (established in 1914) was a BR of the first generation (endorsed in 1979), covering exclusively conservation, research and education functions. This resulted in additional research interest for the EBR, which offered new research opportunities in contrast to the National Park research priorities. Public participation and land-use activities in the buffer and transition zones opened up opportunities for research in social, economic, transdisciplinary and sustainability sciences. Indeed, the EBR attracted many Swiss research teams in human geography and sustainability whose work continues today (e.g. Norman Backhaus, University of Zurich; Thomas Hammer, University of Bern).

The early research activities were strongly shaped by management questions that arose during the establishment of the EBR (Wymann von Dach 2001). It was the scientific coordinator who translated the 


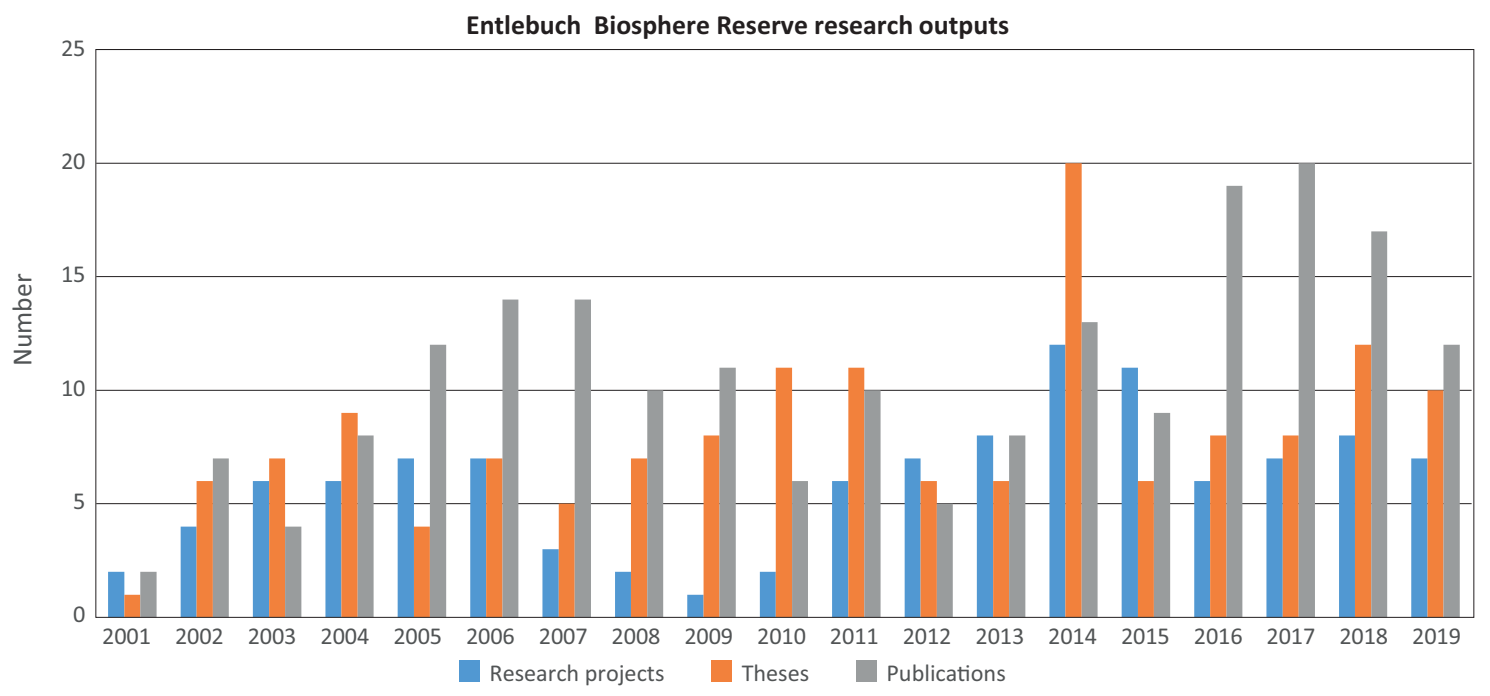

Figure 1 - Number of research projects, theses and publications related to the EBR between 2001 and 2020.

EBR's needs into research questions, sought additional information and support from established research programmes, and linked BR research interests with research teams at national and international levels. One important task was to connect universities and researchers with each other and with local people, making sure that investigations were well adapted to the area, and that the local communities were not overwhelmed by scientists from all over the world. In this period, participatory research principles were introduced, for example through the EU-funded project Visuland headed by ETH Zurich, which involved local communities in designing 3D scenarios for the future development of the EBR (Schroth et al. 2006). The start-up phase was a process of mutual learning between local people and scientists, and of adjustment of the BR concept to local realities (Ruoss \& Alfarè 2018). Another important task was information and communication: existing scepticism and resistance towards research had to be reduced and confidence established.

Research was carried out as theses (BSc, MSc, PhD), or as larger projects financed by the Swiss National Fund, EU Research Frameworks (FP 5 and 6) and Interreg Programmes. Research funds were never made available by the EBR management itself, except for logistical support in relation to data, networking and literature, assistance in planning (e.g. with GIS), or involving cantonal and national administrations. This lack of research funds within the EBR itself persists today, despite the legal obligation to carry out research in BRs introduced in 2007 at national level (BAFU 2014).

Early research activities were coordinated by an EBR research platform, where research offers, needs and priorities were discussed, and stipulated in the first research framework in 2002 (Ruoss et al. 2002). Research at this time was not planned or implemented in any systematic fashion, but depended on funding opportunities and the motivation of scientists to conduct research in the EBR. This is demonstrated by the fact that monitoring baseline-data are partly missing for the pre- and early phases (1997-2001, and 2001ca. 2006 respectively). Ecological and socio-economic data were gathered systematically at this time only by cantonal and national institutions (e.g. peatland, flora, fauna and forest inventories, and socio-economic statistics). Other data were gathered in research projects that served as a valuable database for many researchers who themselves expanded this database further. To make data available, a local GIS model was established in cooperation with the cantonal administration. This model served simultaneously the BR management in elaborating maps for the management and research activities, and the municipalities as a database for territorial planning. These were important first synergies between the EBR, research and local communities, using what at the time was state-of-the-art technology. It is one example of research introducing innovations in the rural area of Entlebuch.

In the early years of the EBR, an important foundation for research was created by introducing participatory research and attracting a wide range of researchers. This approach generated interesting results and promoted the EBR as an area for research at the interfaces of society, the economy, ecosystems, nature and biodiversity. The outcome was an increasing number of research projects, theses and publications up to 2007 (Figure 1).

After ER left in 2006 and a phase of transition with vacancies and changes in personnel, FK was appointed scientific coordinator in 2008 . At this point, collaborations, theses and research projects were resumed, leading to a relatively steady output (Figure 1), but there was also a need to restructure the research management. The earlier research framework was therefore revised. The resulting research concept subsumed the most important strategies for investigations, research 


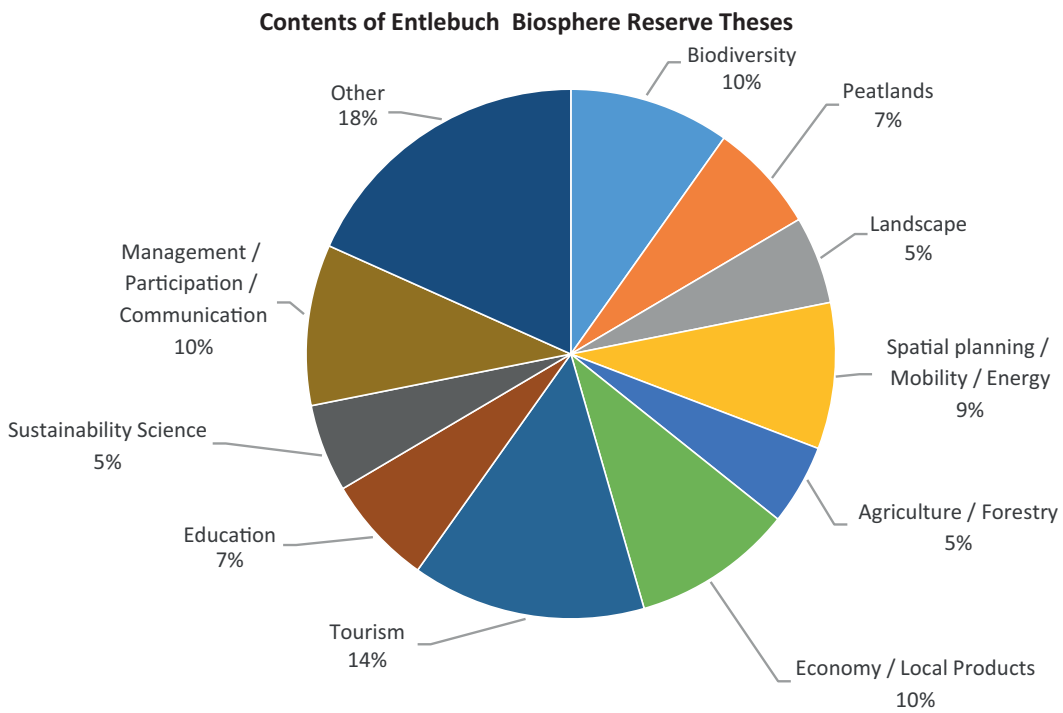

Figure 2 - Topics of MSc, BSc and semester theses between 2001 and 2020 by category $(\mathrm{N}=224)$. Only main topics are considered; many theses covered more than one topic.

fields and gaps, organization, collaboration and knowledge transfer (Knaus 2016), and provided the basis for a more systematic research approach. Subsequently, many gaps in the knowledge that are of high importance for the EBR have been systematically tackled in recent years, e.g. relating to the EBR's impact on the development of the area.

Another aspect of restructuring was a more rigorous approach to an integrated monitoring scheme and a return to evidence-based management, similar to the one during the setting-up phase of the EBR. In the context of the first 10-year management plan for the EBR (Schmid \& Schnider 2017) and the recurring 4-year project / funding plans (Swiss NFA financing rounds), research results and monitoring data were used systematically to identify and tackle gaps in the EBR's management activities. One final aspect of restructuring was the introduction of databases for past and current research activities, outputs and outcomes. These have already proven very useful, indicating the crucial importance of saving raw data for repeat investigations at later stages to gain insights into the transformation processes of specific aspects of the EBR. Unfortunately, however, data was not archived systematically in the early phase of the EBR, leading to a loss of data, a loss compounded by changes in data storage systems, retirement of scientists and institutional reorganizations. Hence, interpreting the role of a BR as a site of long-term sustainability research requires a serious and meticulous approach for monitoring, data storage and data management in order to allow quick and simple reviews of research outputs, e. g. which topics have been covered by theses in the EBR so far (Figure 2). The results indicate a fairly even distribution among the three pillars (ecological, social and economic) of sustainability.

\section{Outcomes and impacts}

Restructuring research management was triggered by the $10^{\text {th }}$ anniversary of the EBR in 2011, when the question of the EBR's impact in the region arose. In spite of a substantial quantity of research results and monitoring data, and even a concept for monitoring success (Schmid et al. 2004), it was difficult to attribute changes in the region directly to the EBR or the EBR's management (Knaus 2013). This lack of knowledge was a starting point for systematic impact assessment activities that directly tackled the question of the EBR's contribution to regional development (Schmid et al. 2004). Hence, in 2011 the impact of the EBR on summer tourism was assessed. The analysis revealed that $16 \%$ of tourists visited the region because of the EBR, and these tourists generated an added value of CHF 5 million (Knaus 2012). The investigation will be repeated in 2021. In 2015, the economic impact of park-labelled products was investigated, revealing that a similar added value (CHF 5.8 million) was created by EBR-labelled products in agriculture and forestry (Knaus et al. 2017). In 2017, an international research project on acceptance, identification and commitment of local communities in BRs was launched, enabling for the first time a comparison of BR impacts in different settings and countries (von Lindern et al. 2019; von Lindern et al. 2020). As well as a strong acceptance and identification, the results indicated gaps in the EBR's communication strategy, especially in targeting individual groups of society, and reaching younger generations. Finally, a long-term research programme in the ecological domain was started in 2019 to monitor the quality of peat bogs over the next 20 years. These investigations are designed methodologically to serve the EBR's monitoring function. They generate insights in the social, economic and ecological domains and provide systematic information on the 


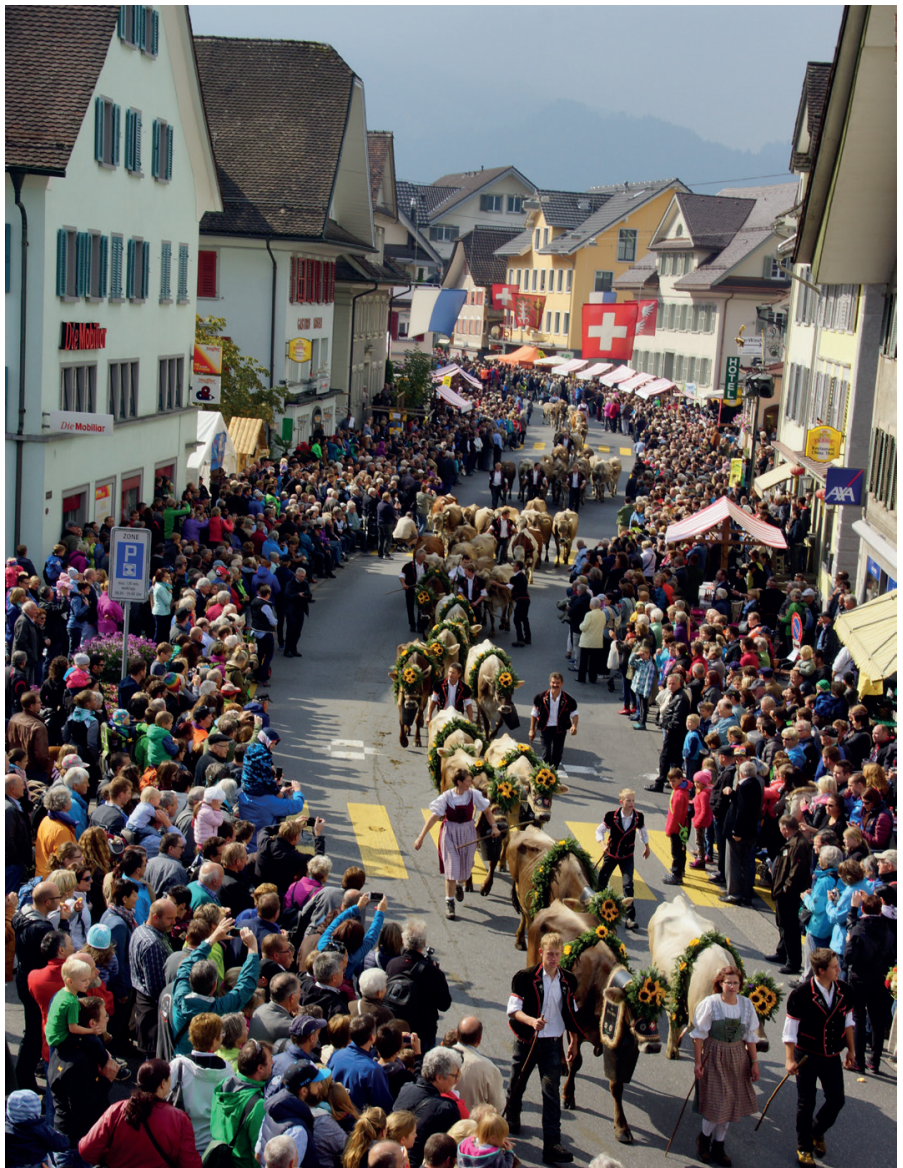

Figure 3 - The Alpabfahrt in autumn attracts over 10000 visitors, who buy local cheese and meat products. (C) UNESCO Biosphäre Entlebuch

impact of the EBR in the most relevant fields of activity over the long term. This information will be crucial for political decision-making processes in the EBR, but also within Switzerland and potentially abroad.

On the more specific question of impacts emanating from research carried out in the EBR, a review of now-historic research results revealed some tangible examples. The most prominent is the Alpabfahrt, where the alpine farmers walk their cattle from the mountain pastures back to the lower villages. This traditional activity almost disappeared, as in many other areas, and was suggested as a possible tourist event in an early research project (Lacope). The idea was discussed and approved by local agriculture associations and promoted as a folkloric event for the first time in 2004. Today, it is one of the largest events in Entlebuch, attracting over 10000 visitors every year (Figure 3). The same research project generated the first cadaster of alpine farms in Entlebuch and suggestions for hiking routes. Based on another research project (Biologic@), a sales platform for organic products was established in 2008. Investigations carried out in the context of BSc and MSc theses led to other developments: a study on the acceptance of windmills served as a basis for a bottom-up installation of a wind farm; mapping of ant hills by volunteers served as a basis for their conservation; species protection projects within the EBR were launched following a systematic review of species of conservation concern; the assessment of the quality of urban green areas led to activities in biodiversity conservation in one of the villages. Numerous MSc theses in didactics have served to enlarge the pool of teaching materials that are used by local teachers in their mandatory classes on the EBR.

EBR research has also influenced practice elsewhere, and the scientific community. A first review of possible monitoring variables for the EBR was picked up by various other Swiss parks, for which it served as a basis for identifying their own sets of indicators. The investigations on added value generated through tourism attracted a lot of attention in the media and the Swiss park management community. With the support of Swiss Park Research / Parkforschung Schweiz, the findings were developed into a how-to guide for carrying out studies on the economic impact and potential added value of tourism in other protected areas (Knaus \& Backhaus 2014); the guide has since been further developed methodologically (Knaus 2018). Additional improvements will be made following the next assessment of the EBR in 2021. The continuous work on the monetary impacts of tourism in PAs has led to scientific innovations that have served and will serve other parks in their own management and research activities.

Based on data from eight different BRs, the most recent study on acceptance, identification and commitment of local people (von Lindern et al. 2019; von Lindern et al. 2020) established an initial basic understanding of the inter-relatedness of these three factors. This international research project, including the constitution of an advisory board of relevant researchers, was enabled by the logistic and financial support of Swiss Park Research. The project's results were well received by national MAB committees. Finally, the project aimed to contribute important and so-far largely missing fundamental insights into social monitoring, following up early ideas of UNESCO's integrated socio-economic monitoring (BRIM, Lass \& Reusswig 2002). There have been many positive and unintended side effects of this highly collaborative project, including stronger future collaboration between the managements of the BRs involved, collaborations in follow-up research projects, and the understanding that many BRs share the same challenges in attracting the interest of society as a whole (von Lindern et al. 2020).

\section{Future challenges and conclusions}

Research in the EBR has created many tangible results for local people, as well as for the EBR's management and for important stakeholders such as local, cantonal and national authorities. It is one of the main tasks of the scientific coordinator and his team to translate scientific results and to direct and disseminate the information in readily accessible form to target au- 
diences. Research in the EBR has also advanced various scientific fields, by providing highly relevant questions, sharing data, and supporting researchers with both practical and theoretical insights and experiences. This has helped many researchers to get in touch with local realities, thus improving the applicability of their results. Bridging the gap between science and local people will remain a challenge: after two decades of setting up collaborative and transdisciplinary research, many early local enthusiasts involved in participative processes have retired or moved on. The significance of the EBR for younger generations is not as evident as for the pioneer generation, making it more difficult to motivate them for active participation.

Global challenges such as climate change, biodiversity loss, socio-economic transformation or limited natural resources, all part of the UN Agenda 2030 and further defined in the SDGs, are research fields of increasing significance also for the EBR. BRs are seen as ideal places to establish new research interactions and to explore and test innovative solutions to overcome these challenges. Adopting new governance and management approaches will be crucial to advance research and its implementation, and to find ways to progress effectively in balancing conservation and development in protected areas (Alfarè \& Ruoss 2020). Using transdisciplinary research projects in which research questions from global challenges are transferred and adapted to local evidence relevant to local stakeholders will be key. To achieve impacts through research, the community needs to be more closely involved in project planning as well as implementation, and colearning / co-creating processes need to be introduced (Alfarè et al. 2019). Hence, strong, active participation remains a central challenge for research in the EBR.

To foster long-term research in the EBR, it will be crucial to formalize cooperation with universities and research institutes. It needs to be explored whether a forum-type approach like the EBR's first research platform is suitable and feasible, or whether closer cooperation and institutional ties with just one or a small number of universities should be sought, as happens in other countries (Walk et al. 2020). Generally, turnover of staff and affiliated researchers, and internationalism have increased enormously in Swiss universities, making a forum-type organization challenging. Further, there is growing competition for park-related scientists, since the number of Nature Parks is high and increasing in Switzerland. However, the vast amount of data that already exists, the wealth of publications, the numerous networks from local up to international level, and the free logistical services are unique to Switzerland and maintain this area's strong attraction for research.

Moreover, funding opportunities attract research and scientists. It would be an advantage to have institutionalized research funding in BRs, at national and international levels, as postulated by others (e. g. Scheurer 2020). By this means, the impacts of the di- verse sustainability approaches implemented in BRs could be investigated more deeply and systematically, creating valuable knowledge regarding key factors in the transformation of regions and societies towards sustainability (see Reed 2016; Ferreira et al. 2020). The potential of BRs in serving as models for attaining regional sustainability pathways could finally be taken better advantage of.

\section{References}

Alfarè, L.T. \& E. Ruoss (eds.) 2020. Governing Future Challenges in Mediterranean Protected Areas. Rome. CNR Edition.

Alfarè, L.T., E. Ruoss \& A. Boumaour 2019. Governance and Management Systems in Mediterranean Marine and Coastal Biosphere Reserves. In: Nared, J. \& D. Bole (eds), Participatory Research and Planning in Practice. Doi: 10.1007/978-3-030-28014-7_4

Bafu (Federal Office of Environment) 2014. Handbuch für die Errichtung und den Betrieb von Pärken von nationaler Bedeutung. Bundesamt für Umwelt, UmweltVollzug 1414. Bern.

Batisse, M. 1997. Biosphere Reserves: A Challenge for Biodiversity Conservation \& Regional Development. Environment. Science and Policy for Sustainable Development 39-5: 6-33. Doi: 10.1080/00139159709603644

Bouamrane, M., P. Dogsé \& M.F. Price 2020. Biosphere Reserves from Seville, 1995, to building a new world for 2030: a global network of sites of excellence to address regional and global imperatives. In: Reed, M.G. \& M.F. Price (eds.), UNESCO Biosphere Reserves. Supporting Biocultural Diversity, Sustainability and Society: 29-44. New York.

Ferreira, A.F., H. Zimmermann, R. Santos \& H. van Wehrden 2020. Biosphere Reserves' Management Effectiveness - A Systematic Literature Review and a Research Agenda. Sustainability 12: 5497. Doi: $10.3390 /$ su12145497.

Knaus, F. 2012. Bedeutung, Charakteristiken und wirtschaftliche Auswirkungen des Sommertourismus in der UNESCO Biosphäre Entlebuch. Resultate einer umfassenden Gästebefragung. Interner Bericht, ETH Zürich und Biosphärenmanagement UBE. Schüpfheim.

Knaus, F. 2013. Lessons learnt from a monitoring endeavour in the UNESCO Biosphere Reserve Entlebuch. eco.mont - Journal on protected mountain areas research and management 5(1): 55-58.

Knaus, F. 2016. Forschungskonzept der UNESCO Biosphäre Entlebuch 2017-2027. Internal Document UBE Management. Schüpfheim.

Knaus, F. 2018. Charakteristiken von Gästen in vier Schweizer Naturpärken und deren touristisch induzierte Wertschöpfung. Untersuchungen anhand des Parc Jura vaudois, Parc Ela, Naturpark Gantrisch und Landschaftspark. Binntal. Projektbericht. Netzwerk Schweizer Pärke and ETH Zürich. Bern and Zürich. 
Knaus, F. \& N. Backhaus 2014. The economic impact of tourism in Swiss Parks. Swiss Academies of Sciences, Fact Sheet 9(3). Bern.

Knaus, F., L. Ketterer \& D. Siegrist 2017. The economic impact of labeled regional products: The experience of the UNESCO Biosphere Reserve Entlebuch. Mountain Research and Development 37(1): 121-130.

Lass, W. \& F. Reusswig (eds.) 2002. Social Monitoring: Meaning and Methods for an Integrated Management in Biosphere Reserves. Report of an International Workshop. UNESCO, Biosphere Reserve Integrated Monitoring (BRIM), Series 1. Paris.

Reed, M.G. 2020. Conceptual origins and first generation biosphere reserves. In: Reed, M.G. \& M.F. Price (eds.), UNESCO Biosphere Reserves. Supporting Biocultural Diversity, Sustainability and Society: 13-28. New York.

Reed, M.G. 2016. Conservation (In)Action: Renewing the Relevance of UNESCO Biosphere Reserves. Conservation Letters 9(6): 448-456.

Ruoss, E., B. Schmid, T. Schnider \& A. Schmid 2002. Grobkonzept Biosphärenreservat Entlebuch. UBE Management. Schüpfheim.

Ruoss, E. \& L.T. Alfarè 2018. Shifting protected area strategies to evidence based governance and management. Conference Volume, 6th Symposium Research in Protected Areas, 2017: 561-564. Salzburg.

Scheurer, T. (2020): Das MAB-6-Projekt der UNESCO: Von der Ökosystemforschung zum MAB Biosphere Reserve. In: Borsdorf, A., M. Jungmeier, V. Braun \& K. Heinrich (eds.), Biosphäre 4.0. - UNESCO Biosphere Reserves als Modellregionen einer nachbaltigen Entwicklung: 85-98.

Schmid, A., Ruoss E. \& H. Elsasser 2004. UNESCO Biosphäre Entlebuch: Modell für eine nachhaltige Regionalentwicklung? Konzept Zielerreichungskontrolle. Geographica Helvetica 2: 144-153.

Schmid, A. \& T. Schnider (eds.) 2017. Labelgesuch UNESCO Biosphäre Entlebuch 2018-2027. UBE Management. Schüpfheim.

Schroth, O., U. Wissen \& W.A. Schmid 2006. Developing new images of rurality - interactive $3 \mathrm{D}$ visualizations for participative landscape planning workshops in the Entlebuch UNESCO Biosphere Reserve. disP 166(3): 26-34.

UNESCO 1984. MaB Action plan for biosphere reserves. Nature and Resources. Vol. XX, 4. Paris

UNESCO 1996. Biosphere reserves: the Seville Strategy and the statutory framework of the world network. Available at: https://unesdoc.unesco.org/ark:/48223/ pf0000103849 (accessed: 10/03/2020)

UNESCO 2008. Madrid Action Plan for Biosphere Reserves (2008-2013). Available at: https://unesdoc. unesco.org/ark:/48223/pf0000163301 (accessed: 10/03/2020)

UNESCO 2017. A new Roadmap for the Man and Biosphere (MAB) Programme and its World Network of Biosphere Reserves: MAB Strategy (2015-2025). Lima
Action Plan (2016-2025), Lima Declaration. Available at: https://unesdoc.unesco.org/ark:/48223/ pf0000247418 (accessed: 18/03/2020)

von Lindern, E., R. Knoth \& X. Junge 2019. Akzeptanz, Identifikation und Engagement: Ansichten und Mitwirkung der Bevölkerung in UNESCO Biosphärenreservaten (AkIdEn). Forum Landschaft, Alpen, Pärke - Akademie der Naturwissenschaften Schweiz (SCNAT) \& Österreichisches Nationalkomitee für das UNESCO-Programm "Man and the Biosphere". Doi: 10.1553/ MAB-AkIdEn. Bern und Wien.

von Lindern, E., R. Knoth-Letsch, V. Härig, C. Klenovec, M. Hunziker, A. Wallner \& F. Knaus (2020). Akzeptanz, Identifikation und Engagement. Ergebnisse und Implikationen aus einer Bevölkerungsumfrage in acht Biosphere Reserves in der Schweiz, Deutschland und Österreich. In: Borsdorf, A., M. Jungmeier, V. Braun \& K. Heinrich (eds.). Biosphäre 4.0. - UNESCO Biosphere Reserves als Modellregionen einer nachbaltigen Entwicklung: 121-138.

Walk, H., V. Luthardt \& B. Nölting 2020. Participatory learning for transdisciplinary science in biosphere reserves. In: Reed, M.G. \& M.F. Price (eds.), UNESCO Biosphere Reserves. Supporting Biocultural Diversity, Sustainability and Society: 297-308. New York.

Wymann von Dach, S. 2001. The Biosphere Reserve as Living Space: Linking Conservation, Development and Research. An interview with: Engelbert Ruoss of the Entlebuch Biosphere Reserve, Switzerland. Mountain Research and Development 21(2): 128-131.

\section{Authors}

\section{Florian Knaus}

works at the interface of research and practice. $\mathrm{He}$ is the scientific coordinator at the Entlebuch UNESCO Biosphere and senior lecturer in the field of conservation and development at the Institute of Terrestrial Ecosystems, ETH Zurich. ETH Zürich, Institute of Terrestrial Ecosystems, Universitätstrasse 16, 8092 Zürich \& UNESCO Biosphäre Entlebuch, Chlosterbüel 28, 6170 Schüpfheim

\section{Annette Schmid}

works at the management of the Entlebuch UNESCO Biosphere. She coordinates strategic planning and reports to the Swiss government and UNESCO. UNESCO Biosphäre Entlebuch, Chlosterbüel 28, 6170 Schüpfheim

\section{Engelbert Ruoss}

teaches World Heritage and Tourism at the Università della Svizzera italiana (USI), and is an Associate Expert at the USI UNESCO Chair. He is a former Director of EBR and was the Reserve's Science Coordinator 1998 - 2006. USI - Università della Svizzera italiana - UNESCO Chair 